Louise Brangan, Pastoral penality in 1970s Ireland: Addressing the pains of imprisonment, Theoretical Criminology (Forthcoming). Copyright (C) The Author 2019. Reprinted by permission of SAGE Publications.

\title{
Pastoral Penality in 1970s Ireland: Addressing the pains of imprisonment
}

The Republic of Ireland is said to be an exception within Anglophone penal history, where it resisted the punitive turn of the 1970s and a more pragmatic and dispassionate penal politics prevailed. Even during the 1970s, when Ireland displayed tendencies towards penal welfarism, this is argued to have been more rhetorical mimicry than commitment to the principles of offender transformation. This article first interrogates these claims by providing an in-depth historical and sociological analysis of penal culture and transformation in the prison system in Ireland in the 1970s. By conducting this analysis in conversation with penological theory, in this case penal welfarism, the study presents a new concept of parsimonious penal power: pastoral penality. Pastoral penality was a more humane penal culture that emerged during the 1970s in Ireland. It is hoped that these historical and theoretical contributions developed throughout this paper contribute to the shifting and deepening of our USA and UK-centric understandings of punishment history and patterns.

The key features of penal welfarism are presented first. This is followed by an overview of the main conventions in Irish penal and social historiography. The substantive historical findings from the research are then outlined. The evidence reveals a counter-narrative of an intentional and highly principled penal transformation led by those who held the power to imprison. The concept of pastoral penality is then forwarded. This was a more humane and empathetic approach to imprisonment that reflects Ireland's socio-cultural and political context, shaped by a conservative political ethos, Catholic values and a communitarian class structure. A wider lens then permits us to also to see that this form of penality was contingent on Ireland's distinctive field of social control, however. The article concludes by acknowledging the structural and practical limits of pastoral penal welfarism but emphasising that while pastoral penality is non-abolitionist it operates with a deep scepticism of the prison and an awareness of the harms it causes. 


\section{Penal Welfarism}

By the 1960s penal welfarism was the established logic of British and American penality (Garland 2001; Feeley and Simon 1992). In practice penal welfarism was correctional, interested in reducing recidivism through rehabilitative interventions, with a positive emphasise on re-education and reintegration of offenders. The penal welfare approach was underpinned by its social and political context, underlain first by a foundation of 'legal liberalism' (Garland 2001:27) that encouraged a rational approach to individual rights, due process and a proportionate distribution of justice (Feeley and Simon 1992). Second, a penal welfare approach was ideologically connected to state welfare, where the state was charged as the provider and protector of its citizens' wellbeing. In addition, penal welfarism was underpinned by the modernist context that prevailed in Britain and the USA (Garland 2001:40-41), shaping a commitment to rational scientific reason. Confidence in the superior authority of social science and psychological expertise led to 'down-playing the role of informal action on the part of the public' (ibid.:32). Hence, crime was understood as a technical matter whereby effective treatments could be developed to achieve the aims of reducing reoffending (ibid.:27-36). Thus, 'in the world of penal welfarism it came instead to be no treatment without diagnosis, and no penal sanction without expert advice' (original emphasis, ibid.:37; Loader 2006). There was a pronounced confidence in the state's rehabilitative and crime control capacities (Garland 2001:33-34): prison regimes could be progressive transformative spaces when used in tandem with the right corrective and reeducative interventions. Such that prisoner classification, indeterminate sentences and individualised treatment were central to imprisonment in order to maximise the prison's positive effect. Penal welfarism captures an entire penal culture: the ways of thinking and feeling within a particular historical moment up until the 1960s that shaped actual prison practices. This state of affairs began to unravel in the 1970s when, it is widely argued, a punitive descent overcame the North Atlantic nations. Penal welfarism faced a crisis of acceptability, increasingly rejected as an outmoded 'old penology' (Feeley and Simon 1992). Integration practices and individual treatment were displaced in favour of punitive segregation (Garland 2001) and actuarial techniques (Feeley and Simon 1992). These penal welfare/punitive turn narratives are often presented on a grand scale, intent on capturing 
the prevailing, and entirely contrasting, epochs of Anglophone penal transformation (Goodman 2012; Goodman et al 2017).

This theoretical and historical account may suffer from restrictions, however. These theories privilege Britain and the United States at the nation state level (rather than as complex multilevel democracies) as the 'centre' of theoretical significance (Aas 2012; Carrington et al 2016), leaving their broad generalisability open to doubt. Looked at on the regional and state level, there were highly varied commitments to penal welfare principles and practices, with the end of rehabilitation era far less swift and certain than sometimes portrayed (Barker 2009; Schoenfeld 2012; McAra 2008). Additionally, across time and place, rehabilitation penal welfarism's raison d'etre - does not appear to carry the same steadfast social meanings and penal intentions (Goodman 2012; Robinson 2008). If, as Barker has shown, that welfare and punishment work to preserve 'a sense of belonging and place' (2017:8), then its means and aims will varying depending on history, culture and politics. These dominant generalised theories of penal transformation, moving from welfare orientated to punitive, risk over-simplifying the complexity of social meanings, penal policies and changing practices that give punishment its forms. These theoretical and empirical limits may reveal the need to develop new alternative concepts of penality that capture penal ideas and functions that deviate from the penal welfare and punitive turn dichotomy. This research explores these issues by examining a period of penal transformation in the Republic of Ireland in the 1970s.

\section{Irish Penal Historiography}

While Ireland is part of the geopolitical context that constitutes the Anglophone world it is rarely included in research that lays claims to these overlapping regions (e.g. Garland 2001; Pratt and Eriksson 2013). I suggest that Ireland's absence from what we imagine when we discuss Anglophone penal history minimises our memory of punishment in this small part of the world and diminishes the breadth and purchase of our analytical insight. Thus, at the very least, an historical and analytical investigation of Ireland may expand our theoretical horizon and challenge the assumptions embedded in our historical narratives. 
Ireland is also particularly interesting as a special case-study of penal welfarism and Anglophone penal transformation because as rehabilitation waned in the 1970s, in Ireland the term was first adopted in legislation in the Prisons Act 1970. It is argued by some that this moment of penal change, the formal adoption of rehabilitation, lacked ideological commitment, apparently marking little more than a discursive shift, giving the appearance of penal welfarism without a subsequent systematic or ideational reorientation (Rogan 2011; Kilcommins et al 2004:287). Instead Irish penal practice has rarely been 'supported by reference to a set of clear principles' (Kilcommins et al 2004:292-293), reference to academic or other professional expertise, essentially operating in what is widely described as a 'vacuum' (Rogan 2011; Griffin and O’Donnell 2012). As a result, in lieu of political principles, the dominant terms employed to describe Irish penal history before the 1990s are 'stagnation' and 'pragmatic' (O’Donnell 2008; Rogan 2011; Hamilton 2014).

But questions remain. If Irish prisons did not treat or rehabilitate, then in what ways were people imprisoned? What sorts of programmes and regimes were prisoners subject to? What expectations were made of prisoners and prisons? Moreover, no decision is ever merely pragmatic - even the most baldly straightforward choice is a constellation of 'principled positions often unintelligible to their promoters' (Freeden 1996:18). What did civil servants think about prisons, what problems were raised, and what solutions did they pursue? These are significant questions that remain to be answered and would yield new theoretical insights if subject to a fuller historical recovery. In light of these gaps, an aim of this paper is also socio-historical, to reveal how people were imprisoned in Ireland and what social, political and culture forces lay behind these practices.

\section{Case-study and Methodology}

This article tracks the late emergence of penal welfarism and its practical out-workings in Ireland from 1970-1980 by focusing on prison policy. This specifically includes the opening of four new prisons, the appointment of prison professionals and the development of a parole system. Using archival research, I collated official publications and a number of unpublished research reports and notes, several of which have not been analysed before as 
far as I am aware. ${ }^{1}$ In addition, I conducted oral history interviews with seven Irish Prison Division civil servants - Jim, Liam, Niall, Gerard, Seamus, Pádraig, and John. ${ }^{2}$ This material provides thick descriptions of how officials felt in conducting their work, providing vital illumination of their thinking, their construction of the penal problem, and the pattern of taken-for-granted considerations which governed their actions (Brangan 2019; Loader and Sparks 2004). These primary materials are weaved together in the analysis with secondary data that maps the social, cultural and political context of Ireland during the 1970s. This historical recovery and reinterpretation are done to support the equally central theoretical aim of the paper. By including an empirical study of Irish prison history in a more thoroughgoing conversation with dominant penological theory may extend our prevailing concepts of penality. Indeed, taking a more grounded approach to penal change and history can help generate new penological theory (Barker 2009; Page 2011; Goodman et al 2015).

\section{0s Ireland}

Ireland became an independent state in 1922. From its inception as a nation, Irish cultural, political and social life was dominated by the Catholic Church, ${ }^{3}$ which was a colossal power bloc (Inglis 1998) whose interests were reflected in legislation, policy and the machinery of social control (ibid.; Fahey and McLaughlin 1999). Rather than rationality and science-based reasoning of modernism, Christian morality and conservative politics shaped the political and social character of modern Ireland.

Religious regulation was most pervasive and censorious when it came to the family unit (Whyte 1980; Canavan 2012; Mohr 2017; Fahey and McLaughlin 1999) which was considered the rudiments of a strong Irish society. The 1937 Irish Constitution - its creation a joint

\footnotetext{
${ }^{1}$ Some of the key material referenced was produced in the early 1980s, when those inside the Prison Division began to see a value in written policy statements. While slightly outside the period under study, these reports are included because they pertain directly to the developments that occurred only a few years early in the 1970s. These documents were also authored by leading actors involved in the 1970s prison developments, who now sought to outline and justify their approach to prison policy in order to ensure its long-term future. Moreover, interviewees suggested that if I could find these documents, they would precisely illustrate what they were trying to achieve during the 1970s.

2 The small number of interviewees reflects the scale of the Irish Prison Division, though the people interviewed reflect the various areas of work in the Division: release, psychology, education, administration and management. Interviews lasted between two and three hours. All interviews were recorded and fully transcribed. All names are anonymised. ${ }^{3}$ By the 1970s Ireland was exceptionally homogenous, with over 90\% of people identifying as Catholic (Ferriter 2012:5).
} 
enterprise between the government and the Irish Catholic Hierarchy - demonstrated that the family unit was central to Irish social order: 'The State recognises the Family as the natural primary and fundamental unit group of Society, and as a moral institution possessing inalienable and imprescriptible rights, antecedent and superior to all positive law'. It went on: 'The State, therefore, guarantees to protect the Family in its constitution and authority, as the necessary basis of social order'.

It is widely argued that 'no society in Europe so exalted the ideal of the family in its official rhetoric' as the Irish (Lee and O'Tuataigh 1982:15). Families were not entirely autonomous units, however: they existed in community networks. Irish class relations were largely communitarian and less rigidly hierarchal than those in Britain (Coakley 1999:50-51). Ireland's general 'absence of class based cleavages' (Chubb 1992:33) allowed a national 'culture of community' (Hazelkorn and Patterson 1994:52) to prevail. As a result, Irish identity and social life had a deeply embedded ethos shaped by a sense of 'community, kinship and mutual aid' (O’Dowd 1987:44).

Catholic cultural forces and conservative social influence also significantly shaped Ireland's austere field of social control. The Church operated as a shadow authority structure in Ireland, and 'while the rest of Europe secularized its institutions and culture the Irish commitment to religion was sustained and even intensified' (Girvin 1986:62). In an important work of historical recovery O'Sullivan and O'Donnell (2007) have illustrated the novelty of imprisonment in modern Ireland. They demonstrate Ireland's staggering use of 'coercive confinement', such as Mother and Baby Homes, Industrial and Reformatory Schools, Borstals, Magdalene Laundries and state-run Asylums. So, while crime was statistically low, with Ireland described as a 'policeman's paradise' (Brady 1974:240), and prison had a per capita use of 16.5 per 100,000, as late as 1951 \% of the Irish population (more than 1,000 per 100,000 people) were coercively confined in one of these other institutions. The monopoly on legitimate violence was not entirely controlled by the democratic state, therefore, instead the penal culture prior to 1970 had cohered around matters of morality and deviance which empowered non-state actors. In line with conservative political thinking then, social problems and the capacity to punish, chastise, 
stigmatise and control deviant Irish populations was felt to be better addressed by traditional social units and institutions, such communities, families and the Church.

These socio-political relations existed in a context of abiding poverty and emigration, described as the phenomena of 'the vanishing Irish' (O'Brien 1953), mass emigration shaped and regulated Irish life (Delaney 2000), and this remained the case until the 1970s. It is argued that migration functioned as an additional, if somewhat inadvertent form of social control, 'sweeping social problems aside' (Fanning 2007:1), such as unemployed young males, and maintaining the quotidian image of Irish purity as homogenous, Catholic and family-focused. Following this argument, Brewer et al (1999:177) suggest that emigration served to subdue crime rates as young adults left Ireland.

At the end of the 1960s/early 1970s there was a short-lived improvement in Ireland's economic fortunes, however. In the face of chronic poverty, industrial and economic stagnation, the Irish government began to assume a greater responsibility for the health and well-being of its citizens in the 1960s and for the first time introduced welfare provisions (Fahey and McLaughlin 1999; Cousins 1995). These new welfare ideals coalesced with the existing Catholic and conservative culture within government, however. Even as the welfare state emerged the integrity of the family remained a central relay for government activity, with state welfare being used to maintain the stability and status of the family unit by financially supporting abandoned wives and children, for example (McGowan 2016:9).

In sum, by 1970 Ireland was distinct within the North Atlantic nations. Mass emigration and mass confinement contributed to the international image of nation unperturbed by crime (Adler 1983). Rather than being a liberal democracy interested in perpetuating individual rights, the obligations and ethos of government were informed by conservative values, making religion and morality its 'mainstay' (Freeden 2003). Ireland was a nation defined largely by its communitarian Catholic culture, where family life was paramount to the national order. But by the 1970s there had been a shift, where the state tentatively began to employ welfare to protect and improve the essential social values of community and family 
security - and it was in this political, social and cultural context that Ireland's delayed progressive prison transformation took place.

\section{Prison Developments}

While the 1960s had seen the signs of new ideas creeping into Irish prison policy (Rogan 2011), it was the 1970s that came to be the decade with the most extensive developments in Irish penal practices to date; the 1970s was a decade of first of its kind penal developments in Ireland. Prisons were managed by the Prison Division, a small centralised group of civil servants based inside the Department of Justice in Dublin. They were responsible for a relatively small number of prisoners, 749 in total (almost entirely male) with men prisoners held across three prisons: Mountjoy, Portlaoise and Limerick. Prisoners were only organised into two categories, the large majority being 'ordinary' prisoners, named so to distinguish them from 'subversives', those prisoners whose crimes were related to the Troubles in Northern Ireland. While Irish prison populations had been low, they began to increase in the 1970s, leading to serious concern for the Division, who sought to ameliorate the new phenomenon of prison overcrowding (JUS/2002/2/66). For the first time since the formation of the State the Irish government began expanding the prison system. Like other western and Anglophone nations, the Irish prison population began to rise, and within a few short years the prison estate expanded to seven adult prisons. But a focus upon prison expansion alone is limiting, we must examine how people were imprisoned. 


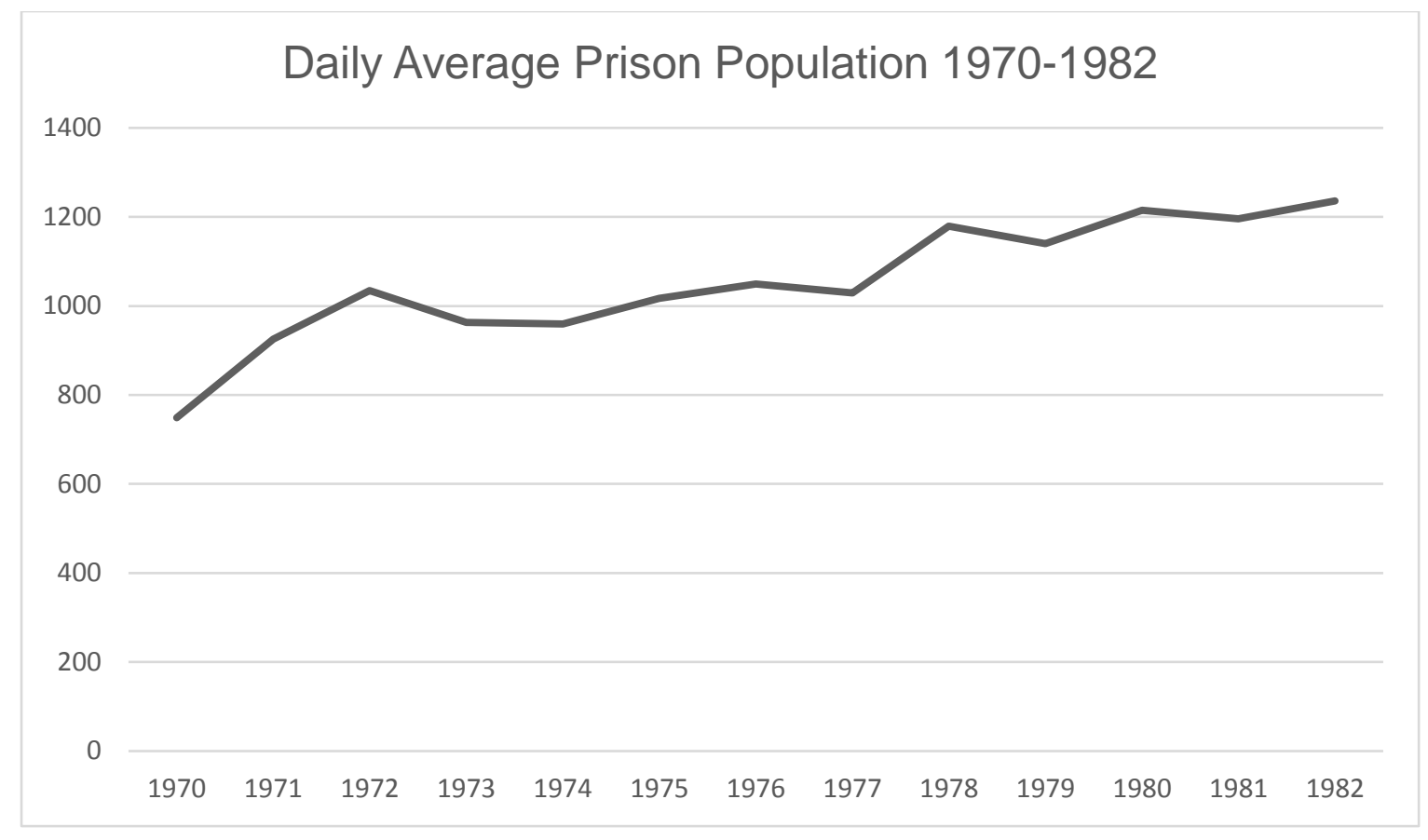

During this period senior Division officials undertook evidence gathering trips to Scotland and Denmark to explore modern prison design (DFA/2009/120/200). Two new closed prisons, Cork and Arbour Hill, were opened in 1972 and 1975 respectively, both of which were former military detention barracks adapted to hold a modest 90 prisoners each. While these two closed prisons were converted buildings, the Division also embarked on a much more ambitious project: The Training Unit, housing between $90-96$ prisoners. This was a highly significant development. Ireland had inherited its penal infrastructure from the British and 50 years after independence the Training Unit was Ireland's first purpose-built prison and was developed with a very distinct set of criteria. The Division was explicit, the aims of the Training Unit were to improve the employment prospects of prisoners at a time of economic prosperity via nationally accredited courses (Department of Justice 1981:3). ${ }^{4}$ The Training Unit was further distinguished because it operated an open ethos that was intended to be less incapacitative and confining. Many at the Training Unit went out to work during the day and returned at night. Internally the regime was designed to mimic

\footnotetext{
${ }^{4}$ This archival document is from Department of Justice files that have not been deposited in the National Archive and therefore do not have an archive code. This, as well as other materials presented to me from retired civils servants, have been referenced in the bibliography as unpublished while using their title and year they were written in the hopes that this makes it easier for future researchers to find these primary archival materials. It should be stressed these archival notes were not reports for public dissemination but were for colleagues' eyes only.
} 
normal working, living and domestic routines, with prisoners allowed to wear their own clothes and permitted to move around the prison without supervision.

The fourth adult prison opened in 1975 was Shelton Abbey, Ireland's first open prison with an average of 35 adult prisoners. Shelton Abbey was a grand country manor - which was referred to as the 'big house' within the Division. ${ }^{5}$ The annual reports proudly stated that the institution was 'in beautiful condition and the improvements are in keeping with such a lovely building' (Annual Report 1979:50). These new prisons were described, in Jim's words, as 'very progressive in terms of penal policy'. John recalled these times with excitement: 'This was maybe going to be the Brave New World of the prisons...this could be the way the system could go, so that was an exciting time'.

The modernising zeal was also steadily reshaping the public presentation of the prison system. By 1976 the annual reports began to include pictures (which had not previously been the case). The images showcased the renovated units and improved conditions homely bedrooms, a modern dental surgery, men playing on glossy badminton courts, men at work, corridors with glistening floors and new industrial training workshops, etc. They explicitly sought to showcase the grandeur of Shelton Abbey, its impressive common spaces with high ceilings and chandeliers, the stateliness of the building's exterior and the extensive grounds. Based on these images, one is left feeling these institutions were hardly like prisons at all, with very little evidence of standard prison iconography, such as barriers, bars and cells. ${ }^{6}$

\footnotetext{
${ }^{5}$ The term big house here is an entirely literal description and obviously means something significantly different to those big house prisons Simon identifies as closed prisons in the USA in the 19th and 20 th centuries (2007:146-147).

${ }^{6}$ Which, of course, were very much still part of the Irish prison system (see Behan 2017). But these changing perceptions inside the Division help us appreciate the changes occurring in how the Irish prison system was organised.
} 

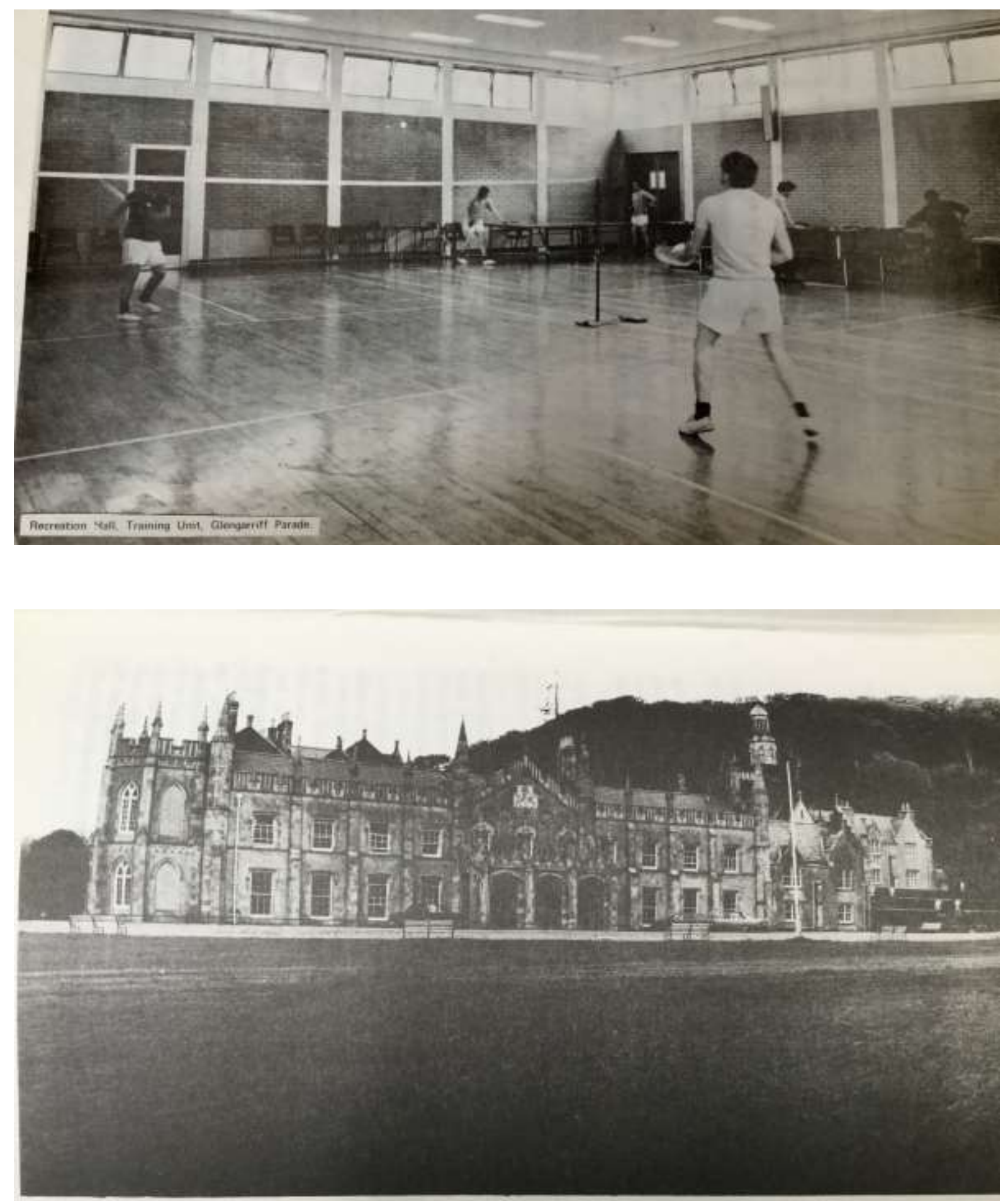

Shelton Abbej- the "open" centre near Arklow for male adult offenders 


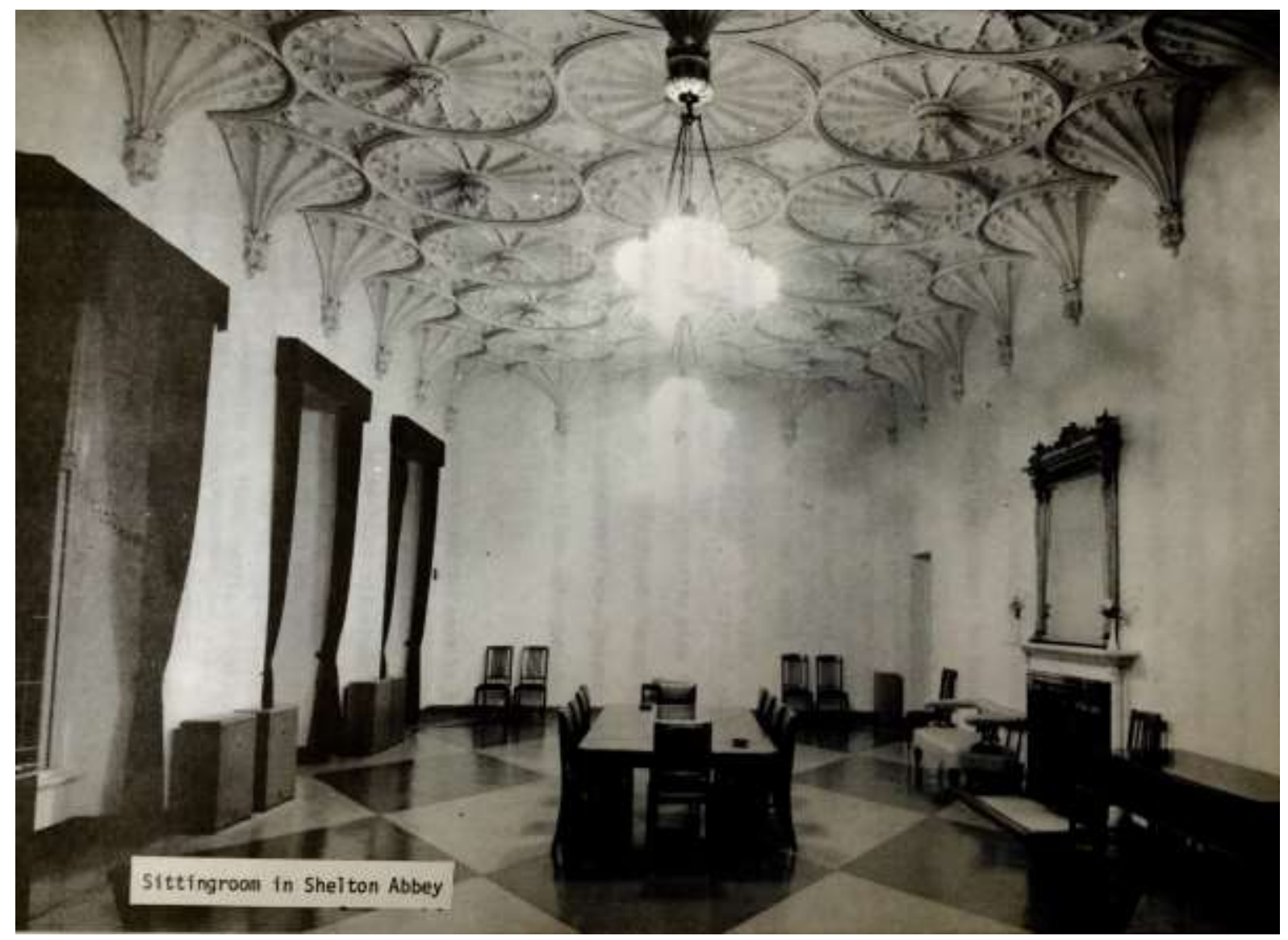

Source: Annual Reports 1970s, various years

The motivation was to give the public 'some idea of the present-day conditions' (Annual Report 1977:6). They wrote that the prisons: 'may still look much the same from the outside but inside things are different' (ibid.). The Division was explicitly demonstrating to the public that the thinking within the Department, what they aspired to, was embedded in the new prison regimes.

In line with these progressive regime developments the Division also created a new array of prison professionals. For the first 40 years or so of the state, welfare support inside prisons was mainly provided by the chaplains. In 1972-1973 the first Directors of Probation,

Education and Co-ordinator of Work and Training were appointed, and four full-time psychologists were hired (Annual Report 1973), allowing the Division to engage with prisoners with what they described as a 'more individual and personal approach' (Department of Justice 1984a:2). 
Incarceration in Ireland had another hugely significant development during this time: the use of temporary release, which was developed in the 1960s (Rogan 2011) but enthusiastically expanded during the 1970s. Prisoners were increasingly released for either short periods during their sentence or fully released before their sentence was complete. There were also mass releases for events such as the visit of the Pope in 1979 (Jewkes and O'Donnell 2011) as well as regular amnesties at Christmas and Easter across the prison estate. There was no parole board, however. While the Minister of Justice was formally charged with the responsibility for granting each release, in reality Prison Division officials were authorised to grant release (Annual Report 1976; Department of Justice 1981). The release decision-making process was shaped by informality, pragmatic need and personal discretion. All prisoners, ordinary and subversive, were eligible for some kind of parole. Nor did prisoners have to serve a certain percentage of their sentence to be considered for it and internal decision-making documents discussing release reveal that there were few crimes which excluded a prisoner from temporary release (Department of 1984a:1-6), it was reported that: 'there was no set pattern in the granting of TR as each case was considered on its own merits' (Annual Report 1979:46).

According to the Minister organising parole this way allowed 'unfettered discretion', which ensured individual cases could be addressed in a 'flexible and relatively unbureaucratic' manner. ${ }^{7}$ Discretionary and individualistic decision-making was a key feature of Irish imprisonment - perceived to be among system's core strengths. After attending an international prison conference officials reported that overcrowding had become an international problem, but no other country used prisoner release quite as liberally as Ireland. It was proudly felt that internationally the Irish release system 'compared favourably' and 'was particularly sound' (3 October 1979, Treatment of Offenders Minutes). Temporary release was understood as central to the Irish style of imprisonment. In fact, it was positively described as having seen a 'noteworthy increase' and they expected, and eagerly hoped, it would grow further still in use and 'variety' (Annual Report 1977:7). Of course, the community setting can be used for extensive penal control (Phelps 2017), release

\footnotetext{
7 This draft ministerial address has no formal reference as it comes from a folder in the Department of Justice storage rather than the National Archives and like other files reference here, was in a series of folders from the early to mid 1980s, but the copy I had was without a specific date.
} 
from the prison should not be presumed as benevolent. However, in 1970s Ireland when someone was released they were rarely subject to the kind of onerous supervisory measures which are now familiar (Healy and Kennefick 2017).

Rather than stagnation or pragmatism we see that in the 1970s Irish penal expansion was informed by innovation. Both the Training Unit and Shelton Abbey presented a less total kind of social exclusion, but all prisons were being made less tight and incapacitative and confining thanks to temporary release, creating a highly permeable mode of imprisonment. The 1977 Annual Report captures this new progressive confidence, opening with a strong statement of achievement and a self-assured public pronouncement: 'Over the past decade there has been a quiet, relatively unpublicised, transformation in the Prison System', revealing what they described as 'a quite revolutionary approach to the handling of those in custody' (p.5-6).

\section{Penal Policy Sensibilities}

What made these new prison practices permissible, even something to be proud of? The motivations driving Irish prison practices becomes clear when we reveal the sensibilities the assumptions, values and beliefs - held by those with the power to imprison.

\section{The Prisoner of Poverty}

Crime was statistically low in Ireland and that may help explain why such permissive and progressive prison regimes developed. In the archives, reports and interviews, crime rarely invoked rebuke or blame, it was often dealt with lightly, particularly in cases being considered for release. Niall, for one, described how many offenders could be a 'dreadful nuisance' but they were released 'because their offences they committed, were not so grave'. Similarly, Jim recalled with considerable amusement, people were often release early who they were sure would re-offend: 'They'd say: "that guy is like a Fiat 127, he'll be fine for two months and then he'll break down again!"' 
There was a certain feeling of tolerance around crime, but this was not just a reflection of statistical patterns. When we think of prison in terms of culture and sensibilities, we see that in the Irish case, understandings of criminality had a direct impact on decision-making. The more lenient uses of imprisonment in Ireland were predicated on a view that people imprisoned were not inherently criminal, the prisoner tended to be defined first by Ireland's endemic poverty rather than a criminal pathology. Many respondents emphasised the tragic and unfortunate backgrounds of prisoners, generally seeing them as victims of chronic economic deprivation. John recalled being explicitly informed of this cultural ethos on his first day in the Division:

'I remember talking to the Principal Officer and he emphasized a few principles to me, which stood to me. Which was the people you will be dealing with...they're from generally underprivileged backgrounds, they're people who haven't had the chances in life you had. And you know, you should bear that in mind in how you approach this work'.

This kind of compassionate sentiment was typical. Jim too stated that 'the concept of person in prison was a humane view of the person, an awareness of their social background being very deprived'. While Liam emphasised the importance of 'the prisoner, their narrative, their history and the notion of socio-economic disadvantage' when discussing his work.

Many interviewees' tolerant sentiments were partially shaped by their own sense of identification with difficulties of forging a successful and stable life in a country riven by poverty. Ireland was poor and prisoners were seen as victims of circumstance; forces of chance and poverty some civil servants understood all too well. Several of the interviewees discussed getting a job in the civil service as a lucky break, the civil service had meant they no longer needed to work in a factory; it gave them a chance to return to Ireland from working abroad. Others had wanted to go to university, but lacked the financial means to do so, the civil service was an interesting alternative with a regular salary. The precariousness of poverty was therefore also part of many of these stories as well. Pádraig best illustrated this employment concern in pithy and explicit terms:

LB: What drew you to the civil service? 
Pádraig: Well, God bless your innocence! What drew me into the service was that I needed a job and that was the only job.

In Ireland, prison policy was partially shaped by an empathy with the prisoners' personal and social circumstances, circumventing a more limited view of prisoners as inherently or pathologically criminal.

\section{Sanctity of the Flock}

However, this social view of criminality alone does not fully account for Ireland's prison practices. Absolutely central to Irish penal culture was the ever-present Irish Catholic conservative virtues of the stable family and the traditions of community, so prevalent in other forms of legislation and social policy. This rationale was the most predominant justification given for temporary release, which had been developed in a manner that could maintain the sanctity of the Irish family unit. Here is a typical general explanation for TR from the Annual Reports:

'Outings for important family occasions such as baptisms, weddings, etc. are a regular feature as are outings on compassionate grounds in the event of the death or serious illness of a close relative... The temporary release system ensures that an offender can return to the family at intervals during his sentence' (Annual Report 1979:22).

Release for short periods was thus 'authorised regularly on compassionate grounds or for very important family occasions' (Annual Report 1976:13) or if a prisoner's 'presence in the home' was required (ibid.:8). Similarly, the practice of offering amnesties for Easter and Christmas recognised that these were major occasions in Catholic Ireland when the entire family usually reunited - and in Ireland that could include family members who were imprisoned.

Crucially, we see that prisoners were understood to still be members of society; their social identities were not overturned. In going about the business of releasing, building and refining the prison regimes, there was an underlying recognition of the importance of family, and the prison was adjusted in ways that preserved community ties and familial obligations. Therefore, we can ascertain that the ad-hoc and 'unbureaucratic' form of release allowed, by design, Ireland's Catholic and conservative cultural ethos to shape decisions, 
rather than objective pro-forma indicators set down by experts that might overlook the social and personal nuances in a prisoner's case.

For Jim, among others, the Department had many flaws (too conservative and not ambitious enough foremost among them), but he was adamant that these prison developments were progressive because they prioritised Ireland's broader social goals above penological objectives:

'the attitude to the prisoners was that we need to help these guys, not address their offending behaviour, not that narrow objective, we've just got to help them. What did we mean by rehabilitation? Maybe they're just better with their family'.

The rationale within the Division favoured the power of the community and the collective as a means to put prisoners back on the right path. However, this statement illuminates an additional characteristic of Irish penal culture, that rehabilitation had a very particular connotation and practical implication in 1970s Ireland.

\section{Rehabilitation: an 'approach to living'}

An internal report outlined the new concept of prison rehabilitation; presented as broadly laudable but its basic aims needed to be made compatible with their aspirations of improving and supporting family and community life:

"While "rehabilitation" is not the primary objective of imprisonment it is nevertheless an important and valid objective. It is intrinsically good and should not be abandoned simply because evidence does not prove that it is "successful". What is to be the measure of success? Is it to be that the prisoner never again engage in criminal activity, or is never again caught, or is never convicted again, or is not convicted again within a certain length of time, or engages in criminal activity less serious in nature than his original offence? What about the qualitative improvement in the prisoner's approach to living, his relationships with family and friends, his involvement in community activities, his willingness to help and support others, his physical and mental well-being?' (Department of Justice1981:7-8, emphasis added). 
In this extended quote rehabilitation as reducing crime was perceived to undermine the more important goal of cultivating and reinforcing social morality in prisoners. Instead, the best prison interventions were not limited to the singular demands of reducing recidivism:

'[the aim is] to equip the offender with educational, technical and social skills which will help him to turn away from a life of crime, if he so wishes. However, even if the offender on release does not turn away from a life of crime, those services can be regarded as having achieved some success if they bring about an improvement in the offender's awareness of his responsibilities to himself, his family and the community' (Annual Report 1982:29).

An improved 'approach to living' was also felt to be best achieved within the community, the family and back at home. Release was justified therefore, according to the Minister for Justice, because it gave priority to the utility of the family:

'obviates the need for rehabilitation programmes and lengthy schemes, which sometimes have low enough success rates for reintegrating prisoners into the community, because here the people are not in prison in the first place. They live at home' (Dáil Debates, June 11 June 1985).

The integrity of the collective loomed large in the prison policy rationale. But this pragmatic insight reveals something else irregular about this conception of rehabilitation: a distinctly suspicious view of the prison, whereby it was seen as a destructive social institution. The prison was what disintegrated a prisoner's social and personal bonds, it was that from which prisoners required reintegrative support. Shortening and softening the use of the prison reduced the need for reintegration and maintained the sanctity of family home life.

\section{Humanitarian Sensibilities: Shepherding the Prisoner Through the Pains of Imprisonment}

Those in the Division often exhibited a scepticism of the prison's positive claims and they were concerned by its damaging effects. The Minister for Justice proclaimed the prison environment was 'basically unsuitable for encouraging individuals to become adequate and responsible members of normal society' (Dáil Debates, May 26, 1970). This is, I argue, more than generic rhetoric, but reflective of a humanitarian penal ethos. Humanitarian penal sensibilities are a distinct outlook that seek to reduce the pains of imprisonment, motivated by empathy and a respect for prisoners as people (Morris 1966; Garland 2010; Brangan 2019). 
A penal culture motivated by a humanitarian view will therefore be more suspicious of the negative impact of the prison rather than the negative characteristics of the prisoners.

Motivated by their humanitarian ethos, the Division was generally working to improve Irish imprisonment, but in ways which sought to reduce the destructive and dehumanising aspects of prison sentences where possible, and this contributed significantly to the shape of Ireland's penal transformation. For example, when temporary release was first introduced the Minister for Justice declared that it would prevent 'the institutionalisation, psychological deterioration and disruption to family and individual life consequent on imprisonment', better to have the prisoner 'in his own milieu' (quoted in Rogan 2011:109). This thinking was particularly evident in the aims of the new support services such as psychology and probation, which were designed to help prisoners cope with the pains of imprisonment. They were 'trying to assist them [prisoners] through counselling to cope with their problems, some of which may arise from imprisonment itself' (Annual Report 1982:38). Education's objectives included: 'helping prisoners cope with their sentences ....[as] one element which might compensate for, or modify the deprivations of prison life (1984b:5 original emphasis). Even psychology, that power-knowledge instrument so closely associated with prisoner reform, was described in terms of coping, focusing on counselling prisoners so as to 'assist them in coming to terms with their imprisonment and with life in the community after release' (Department of Justice 1981:10). Instead of attempting to regulate prisoners' criminality, services supported prisoners in overcoming the pains of their imprisonment. Describing these prison professionals, Niall likened psychology to chaplaincy, a humane cushion to soften the blow of imprisonment rather than fixing people:

'meeting prisoners, discussing their problems, psychological stuff, you know psychologists play a big role, as do chaplains in the human relationships with prisoners'.

Mirroring this, psychological services, according to Liam, used discursive rather than curative techniques: 'in the early days the last thing you would talk about was the crime. It was the well-being, how were they getting on?'. They were intent on shepherding the prisoner through his imprisonment. 
Irish penal culture operated as it did because it recognised the 'destructive agency' of the prison (Armstrong, forthcoming), and where possible, sought to curtail it. As Jim described it: 'prisoners have these needs, so let's make life in prison bearable, it's nothing to do with rehabilitation'. This humanitarian penal philosophy was not entirely taken-for-granted. It was the often passed onto to staff as part of the informal orientation; a way of thinking that should guide their actions:

'I think in those days there was a more liberal approach than there was in more recent times. I told you at the outset about the guiding philosophy given to me... it was all about prison was necessary as a sanction under the criminal law, within that then we should be trying to the best we can... [that was the] guiding philosophy' (John).

As a result, others, such as Liam, also stressed that there had been a 'humanity about the system' in this period. And reflecting on his colleagues' approach to their work in this period, a later staff member, Gerard, thought that there had been a peculiar 'distaste for the whole business' of imprisonment in the 1970s into 1980s. As such, Irish prison practices were motivated by an attempt to address the problems of the prison, not the problems of the prisoner.

Contrary to the literature on Irish penal history, this was a period of progressive penal transformation driven by explicit and implicit intentions and ideas. Ostensibly, prison practices were being modernised. Making imprisonment more permeable the Prison Division were doing more than reducing the prison population; Irish prisons were being adapted in a manner which reinforced the conservative heritage, cumulative social norms and values of the traditional Irish nation.

\section{Pastoral Penality}

This article adds further support to research showing that ideas such as justice and rehabilitation are 'more malleable and multifaceted than is often recognized' (Goodman 2012:439) and that these penal ideas morph and evolve depending on the wider social order (Super 2011; Barker 2017). Moreover, claims that a decisive punitive turn occurred from the 
1970s in the North Atlantic remain open to doubt (Goodman et al 2017). However, while Ireland did not descend into a punitive penal culture in the 1970s like its USA and UK neighbours, nor did it commit to corrective penal welfarism. I suggest that Ireland is therefore not just a case to be added to the literature on the differential emergence, decline and evolution of penal welfarism and the rehabilitation paradigm in the North Atlantic and the West (Schoenfeld 2014; Goodman et al 2017; Pratt and Eriksson 2013). Certainly, like penal welfarism, Ireland's prison developments were intended to be less retributive, and these new prison strategies were occurring simultaneously with the flowering of the Irish welfare state. However, the character of Irish penal transformation in the 1970s doesn't meet the central practical, social and political requirements of penal welfarism. Instead, this study reveals the limits of penal welfarism as a concept that can sufficiently capture the character of most non-punitive prison systems, I argue that the case of Ireland reveals a new form of penality that requires conceptualisation. Following Foucault (1981) and Valverde (1998, 2017), Irish prison regimes were less welfare orientated and instead rooted in a powerknowledge dynamic known as pastoral power. Pastoral governing was a priestly form of power, rooted in Christianity. Though, taken less literally it provides key ideas that more effectively illuminate Irish penal transformation, capturing both the penal practices and historical-cultural context of 1970s Ireland that penal welfarism does not.

When pastoral power hybridises with penal aims it still uses the prison but openly acknowledges that prison always involves the inescapable infliction of pain, seeking to support the prisoners as they face the harms of confinement. As a result of this more benevolent and sympathetic approach to governing the prison is to be made less oppressive rather than more effective, in fact 'pastoral power is anti-quantification and anti-efficiency' (Valverde 2017:29). Pastoral penal power is instead 'highly personalised' and individuated, supporting people through the 'dark night of the soul' (Valverde 1998:47), caused in this case by imprisonment and familial separation; as such, it engages people's suffering without pathologizing them. Specialists informed by a pastoral penal culture will therefore not be designated with the task of diagnosing criminals and providing corrective treatment, such as in a penal welfare context, instead their job will be to act as 'shepherds', providing 'advice and moral support' through lenience (Valverde 1998:47). Like others, the findings here show 
that in the 1970s Irish penal policymakers did not display any belief in the superiority of scientific knowledge professionals (Rogan 2011; O'Donnell 2008). But this is not to uphold the ideational 'vacuum' often suggested. The lack of interest in experts and efficiency was the characteristic of pastoral penality. The Irish prison support services developed at this time - psychology, probation and education - differed in ideational orientation and practice to welfare approaches as they were not centrally linked to the aims of assessment, treatment, and correction, but were intended to have a mainly caring and discursive quality, employing a 'pre-scientific knowledge of an individual's mind and soul' (Hannah-Moffat 1997:7). The aims of prison experts were focused on increasing prisoner ability to deal with imprisonment - and the word 'coping' came up time and again in describing their work - in the hopes of reducing the corrosive impact of the prison upon a persons' social, personal and familial well-being.

The other primary motivation of a pastoral penal culture is communitarian, focusing on 'the flock' (Foucault 1981); the individual is seen as inseparable from the collective (Dean 2011). In this context the pastoral leader must return the fallen individual to 'the fold' of the community (Foucault 1981:229). Unlike liberalism then, the aims of pastoral power are to generate in citizens' hearts and minds a subjectivity bound to their place in the collective rather than improve their sense of individual responsibility (Valverde 2017:29). We see this particularly in how an "approach to living" was described as paramount among Irish prison policy aims: supporting a prisoner's relationships with family and friends and encouraging their community belonging, which was achieved in particular via Ireland's generous and diverse parole arrangements. The primacy of the flock was also highly significant in shaping the more dubious view of the prison. In total contrast to the welfare penal culture that was waning in the rest of the Anglophone world, in Ireland informal social controls of the community were not side-lined but actively embraced. Many in the Division were motivated by a conviction of the superior power of the 'collective efficacy' of the family and community (Sampson et al 1997) because, in contrast to penal welfarism, there was a deep scepticism of the prison as a superior corrective site. In 1970s Ireland, techniques, such as temporary release, rolling amnesties, skills training and open prisons, were being expanded 
to help return the prisoner more regularly and more easily to the normalcy of community and family life.

Such techniques were possible because unlike their welfarist counterparts in Britain and the USA, those working in the Prison Division in Dublin further differed in their penal approach because they were not so interested in reducing crime. In Ireland the view of the prisoner was as misfortunate rather than the more patrician sentiments of the penal welfare habitus (Loader 2006) that viewed prisoners as a dysfunctional client to be treated (Feeley and Simon 1992). By looking after the collective the pastoral leader also recognises the ascetic life and hardship of its flock and is fundamentally a 'lover of the poor' (Brown 1987, quoted in Dean 2011:96) who has a sense of solidarity with the less fortunate. Rather than treating their individual transgressions or recovering them from criminality, Irish penal policymakers recognised prisoners' poverty and suffering. The absences of diverse prisoner groupings, only categorically distinguishing 'subversives', also reflects the homogeneity and 'ordinariness' with which prisoners were understood. That was who prisoners were often believed to be by those in charge of Irish imprisonment, economically marginalised but unfaltering members of communities and collectives, that was how the ideal Irish nation was envisioned, and it was those ideas that were inscribed into the emerging progressive prison practices.

Lastly, while penal welfarism is a product of modernism and liberalism pastoral penality requires a different socio-political context to blossom. As outlined earlier, the ascendant political and cultural currents and social structures in Ireland were conservative, communitarian and traditional. Given that pastoral power is rooted in a traditional Christian culture it also more precisely captures these social forms that helped support Ireland's 1970s penal transformation - buffering Ireland from the punitive trends that were occurring around it and ultimately giving it a distinct from of progressive penality.

We see, therefore, that similar penal tactics (e.g. release, incarceration, rehabilitation, prison education) should not be misunderstood as having sprung from identical social aims and political contexts. Penal welfarism was politically rooted in liberalism and grew out of 
modernism. It prioritised scientific expertise that advocated the prison could be perfected, using techniques founded upon legal, academic and research ideas, in the hopes of making the prison an effective site that could successfully categorise prisoners, treat criminality and re-educate prisoners. Pastoral penality, however, was founded upon conservative political and social forms. When pastoral penality provides the ideational basis for governing imprisonment its aims are driven by compassion and community cohesion, not criminal correction, interested in reducing the pains of imprisonment rather than individual rehabilitation. The prison was viewed sceptically, seen as inherently inhumane and inferior to traditional institutions of family and community for returning an offender to normal life. In this context prison programmes favour discretion to effectiveness, employing open programmes and settings, job training, education and discursive support services that were directly aimed at supporting prisoners cope with imprisonment and develop as people. I argue that rather than being a late or superficial adopter of penal welfarism, it was pastoral penality that was reflected in Ireland's 1970s prison transformation and the intentions that informed it.

However, finally, to have a full critical and sociological understanding of pastoral penality we must situate this parsimonious form of penality within its contingent social control landscape. While the number of prisoners and prisons was expanding, in the 1970s the prison remained a peripheral social control mechanism. Ireland's traditional conservative political outlook had religion and morality as its bedrock, rather than legal concepts and order. Ireland's carceral archipelago of coercive confinement offers ample evidence of the primacy of other more explicitly morally attuned institutions charged with confinement. In addition to that religious welfare control, it is argued Ireland also relied on the 'emigration culture' as a 'safety valve' for its social problems (Fitzgerald et al 2008:51). In a country that was often excluding and oppressive in how it achieved social conformity, in contrast, how the prison operated could be more benevolent, mild and tolerant. The pastoralism of the Irish imprisonment regimes existed not in spite of excessive and harsh Irish social control but was a result of it: The Division could generally indulge and develop ameliorative imprisonment regimes because imprisonment was peripheral, it was not the main coercive means of social control and, in addition, crime was not a major social matter. Meaning the 
social goods of the family and the community could prevail within the Division's penal preferences.

\section{Conclusion}

With this article I hope to have contributed in some way to the maturing of Irish penology, which has been frequently lamented as an 'absentee discipline'. We may now see Ireland's history of penality anew. Those in the Prison Division were not secular liberal professionals with criminological expertise and a refined sense of civic citizenship, they were conservative Catholic civil servants. Their social interests and political intentions were shaped by communitarian ideals and obligations where the hegemonic image of the cohesive family was the central unit of Irish social order. The government's central job was to create a nation where citizens were indoctrinated as productive members of families and communities, and when it came to the prison, its techniques reflected these particular set of concerns. The aims of those in the Prison Division were not tied to modernism but collective morality, giving rise to a pastoral penal culture, and as a result this meant that Irish prisons in the 1970s were coming to be 'ruled through leniency' (Melossi 1994).

It is hoped that the findings also deepen and broaden our USA and UK-centric theories and histories of late twentieth century penal transformation. In particular, the article provides an interrogation of the limits of penal welfarism and in doing so sought to refine and extend our existing penological lexicon by proposing the new concept of pastoral penality to capture the contours of Ireland's parsimonious penal culture. By focusing on places such as Ireland, that are excluded and marginalised in the North Atlantic theoretical narratives, can help 'de-colonize and democratize the toolbox of available criminological concepts, theories and methods' (Carrington et al 2016:1). The concept of pastoral penality generated here may have wider use, possibly in places considered penal exceptions or where penal welfarism has been found to be divergent, modified, or where penal practices are broadly progressive. Hence, the case of Ireland and the theoretical contribution developed here hopefully further demonstrates the importance of developing theory beyond the USA and UK. 
While pastoral approaches are certainly appealing in their parsimony and humane thinking, there are limitations that must be acknowledged. While it was the dominant ideational framework during the 1970s, like penal welfarism, pastoral penality was never wholly dominant in all prison practices (Goodman et al 2017:72; Behan 2017). Pastoralism was also gendered (Hannah-Moffat 1997). Given that the prison system was almost entirely male there were heteronormative limitations on the social imagination underpinning pastoral penality. This was benign inclusivity for men who could be recovered to the traditional and acceptable settings of the family, the workplace and community. For convicted women, their double deviance often incurred a harsher patrician response, such as indefinite coercive confinement (Black 2018). There was also the risk of unbridled discretion being more punitive, where people deemed bad simply would never be considered for release (Department of 1984a). Though this is an enduring problem of even the most regulated and bureaucratic parole systems and not limited to pastoral informality. That said, there are normative dimensions in pastoralism that should remain valuable. Pastoral penality shows that if governments acknowledge firstly that prison, rather than the prisoner, is fundamentally problematic and often harmful (causing unemployment and deepening poverty; deteriorating a prisoner's physical and mental health; stigmatising and labelling people; damaging the wider family's), then there can be a degree of retrenchment in penal control. In Ireland this helped to create alternative penal practices that sought to undermine the prison's grip and impact upon the prisoner and their family, favouring a permissive kind parole and caring rather than transformative forms of intervention.

\section{References}

Aas, K.F. (2012) 'The Earth is one but the world is not': Criminological theory and its geopolitical divisions, in Theoretical Criminology, 16(1) 5-20.

Adler, F. (1983) Nations Not Obsessed with Crime, Littleton: Rothman.

Armstrong, S. (forthcoming) Prison Leviathan: On the Monstrous Agency of Prison.

Barker, V. (2009) The Politics of Imprisonment: How the Democratic Process Shapes the Way America Punishes Offenders, New York: Oxford University Press. 
Black, L. (2018) "On the other hand the accused is a woman...": Women and the Death Penalty in Post-Independence Ireland, in Law and History Review, 36(1):139-172.

Brady, C. (1974) Guardians of the Police, Dublin: Gill and Macmillan.

Brangan, L. (2019) Civilizing Imprisonment: The Limits of Scottish Penal Exceptionalism, in The British Journal of Criminology, Advance on-line access.

Brewer, J.D, Lockhart, B., and Rodgers, P. (1999) Crime in Ireland 1945-1995 in Heath, A., Breen, R. and Whelan, T.C (eds) Ireland North and South - Perspective from Social Science, Oxford: Oxford University Press.

Canavan, J. (2012) Family and Family Change in Ireland - An Overview, in Journal of Family Issues, 33(1): $10-28$.

Chubb, B. (1992) The Government and Politics of Ireland, 3 ${ }^{\text {rd }}$ Ed, Longman, London.

Coakely, J. (1999) Society and Political Culture, in Coakley, J. and Gallagher, M. (eds) Politics in the Republic of Ireland, third edition, London: Routledge.

Cousins, M. (1995) The Irish Social Welfare System: Law and Social Policy, Dublin:Roundhall Press.

Dean, M. (2011) Governmentality: Power and Rule in Modern Society, London: Sage. 2nd ed.

Delaney, E. (2000) Demography, state and society: Irish migration to Britain, 1921-1971, Montreal \& Kingston: McGill-Queen's University Press.

Department of Justice (1981) Survey of Objectives, unpublished.

Department of Justice, (1984a), Prison Numbers and Shedding, Draft Submission to Committee of Inquiry into the penal system, unpublished.

Department of Justice, (1984b), Education Policy in Prions and Places of Detention unpublished.

Fahey, T. and McLaughlin, E. (1999) Family and the State in Heath, A., Breen, R. and Whelan, T.C (eds) Ireland North and South - Perspective from Social Science, Oxford: Oxford University Press.

Fanning, B. (2007) Immigration and Social Change in the Republic of Ireland, Manchester: Manchester University Press.

Feeley, M. and J. Simon (1992) 'The new penology: Notes on the emerging strategy of corrections and its implications', Criminology 30(4): 449-74.

Ferriter, D (2012) Ambiguous Republic: Ireland in the 1970s, London: Profile Books. 
Foucault, M. (1981) Omnes et singulatim/towards a criticism of political reason, Tanner Lectures on Human, 2:225-254.

Freeden, M. (1996) Ideologies and Political Theory: A Conceptual Approach, Oxford: Oxford University.

Freeden, M. (2003) Ideology: A Very Short Introduction, Oxford: Oxford University Press.

Garland, D. (2001) The Culture of Control: Crime and Social Order in Contemporary Society, Oxford: Oxford University Press.

Garland, D. (2010) Peculiar Institution: America's Death Penalty in an Age of Abolition, New York: Oxford University Press.

Goodman, P. (2012) "Another Second Chance": Rethinking Rehabilitation through the Lens of California's Prison Fire Camps, in Social Problems, 59(4):437-458,

Goodman, P., Page, J., and Phelps, M. (2015) The long struggle: An agonistic perspective on penal development, in Theoretical Criminology, 19(3): 315-335.

Goodman, P., Page, J., and Phelps, M. (2017) Breaking the Pendulum - The Long Struggle Over Criminal Justice, New York: Oxford University Press.

Girling, E., Loader, I., and Sparks, R. (2000) Crime and Social Change in Middle EnglandQuestions of Order in an English Town, London: Routledge.

Girvin, B. (1986) Social Change and Moral Politics: The Irish Constitutional Referendum 1983, in Political Studies, 34(1): 61-81.

Griffin, D., and O'Donnell, I. (2012) The Life Sentence and Parole, in The British Journal of Criminology, 52: 611-629.

Hamilton, C. (2014) Reconceptualising Penality: A comparative perspective on punitiveness in Ireland, Scotland and New Zealand, Surrey: Routledge.

Hannah-Moffat, K. (1997) From Christian maternalism to risk technologies: Penal powers and women's knowledges in the governance of female prisons, unpublished $\mathrm{PhD}$ dissertaion.

Hazelkorn, E., and Patterson, H. (1994) The New Politics of the Irish Republic, in New Left Review, 207.

Healy, D. and Kennefick, L. (2017) Hidden voices: Practitioner perspectives on the early histories of probation in Ireland, in Criminology and Criminal Justice, 1-18

Inglis, T. (1998) Moral Monopoly - The Rise and Fall of the Catholic Church in Modern Ireland, $\left(2^{\text {nd }}\right.$ 
edition), Dublin: University College Dublin Press.

Kilcommins, S., O'Donnell, I., O'Sullivan, E., and Vaughn, B. (2004) Crime, Punishment and the Search for Order in Ireland, Institute of Public Administration, Dublin.

Lee, J., and O'Tuathaigh, G. (1982) The Age of de Valera, Dublin: Ward River Press.

Melossi, D. (1994) The "Economy" of Illegalities: Normal Crimes, Elites and Social Control in Comparative Analysis, in Nelken, D. (ed.) The Futures of Criminology, London: Sage.

Mohr, T. (2017) Embedding the Family in the Irish Constitution, in Howlin, N., and Costello, K. (eds) Law and the Family in Ireland, 1800-1950, Basingstoke: Palgrave Macmillan.

O'Brien, J. A. (1953) (ed), The Vanishing Irish, London: W.H.Allen.

O'Donnell, I. (2008) Stagnation and Change in Irish penal Policy, in Howard Journal of Criminal Justice, 47 (2):121-133.

O'Donnell, I. (2008) Stagnation and Change in Irish penal Policy, in Howard Journal of Criminal Justice, 47 (2):121-133.

O'Donnell, I., and O'Sullivan, E. (2007) Coercive Confinement in the Republic of Ireland The waning of a culture of control, in Punishment and Society, 9(1): 27-48.

O'Donnell, I., and Jewkes, Y. (2011) Going home for Christmas: Prisoners, a taste of freedom and the press, in Howard Journal of Criminal Justice, 50(1):75-91.

O'Dowd, L. (1987) Town and Country in Irish Ideology in The Canadian Journal of Irish Studies, 13(2): 43-53.

Phelps, M. S. (2017) Mass probation: Toward a more robust theory of state variation in punishment. Punishment and Society, 19(1):53-73.

Pratt, J., and Eriksson, A. (2013) Contrasts in Punishment - An Explanation of Anglophone Excess and Nordic Exceptionalism. Oxon: Routledge.

Robinson, G. (2008) Late-Modern Rehabilitation: The Evolution of a Penal Strategy, in Punishment and Society, 10:429-45.

Rogan, M. (2011) Prison Policy in Ireland: Politics, penal welfarism and political imprisonment, Oxon: Routledge.

Sampson, R.J., Raudenbush, S.W., and Earls, F. (1997) Neighborhoods and Violent Crime: A Multilevel Study of Collective Efficacy, in Science, 277:918-924.

Schoenfeld, H. (2014) The delayed emergence of penal modernism in Florida, in Punishment and Society, 16(3):258-284. 
Simon, J. (2007) Governing Through Crime: How the war on crime transformed American democracy and created a culture of fear, New York: Oxford University Press.

Super, G. (2012) 'Like some rough beast slouching towards Bethlehem to be born': A Historical Perspective on the Institution of the Prison in South Africa, 1976-2004, in The British Journal of Criminology, 51(1):201-221.

Valverde, M. (1998) Diseases of the Will - Alcohol and the Dilemmas of Freedom, Cambridge: Cambridge University Press.

Valverde, M. (2017) Michel Foucault, London:Routledge

Whyte, J.H. (1980) Church and State (2 ${ }^{\text {nd }}$ Ed) Dublin: Gill \& Macmillan. 